\title{
非マルコフ散逸粒子動力学に基づく水の粗視化モデルの構築
}

\author{
木原 玄悟 ${ }^{* 1}$ ，吉本 勇太 ${ }^{* 1}$ ，堀 玩磨 ${ }^{* 2}$ ，高木 周 ${ }^{* 3}$ ，杵淵 郁也 ${ }^{* 1}$
}

\section{Constructing a coarse-grained water model based on non-Markovian dissipative particle dynamics}

\author{
Gengo KIHARA*1 ${ }^{* 1}$ Yuta YOSHIMOTO*1, Takuma HORI ${ }^{* 2}$, Shu TAKAGI ${ }^{* 3}$ and Ikuya KINEFUCHI*1

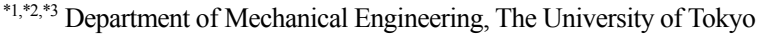 \\ 7-3-1 Hongo, Bunkyo-ku, Tokyo 113-8656, Japan
}

Received: 17 April 2018; Revised: 30 June 2018; Accepted: 20 August 2018

\begin{abstract}
We constructed a coarse-grained (CG) water model based on non-Markovian dissipative particle dynamics (NMDPD) taking into account memory effects. The NMDPD equation of motion was derived from a generalized Langevin equation formulated via the Mori-Zwanzig (MZ) projection operator. We extracted a CG pair potential and memory kernels between clusters comprising 10 water molecules by means of molecular dynamics (MD) simulations. We found that the MZ-guided CG potential followed by an iterative Boltzmann inversion correction resulted in an accurate representation of both a radial distribution function and pressure. Furthermore, in contrast to Markovian DPD, the NMDPD model exploiting MZ-guided memory kernels could reproduce short-time dynamics originating from molecular collisions, which was characterized by decaying nature of a velocity autocorrelation function (VACF). The NMDPD model was also able to reasonably represent the viscosity of the MD system compared to the conventional DPD, where interaction parameters were phenomenologically tuned such that a few macroscopic properties were reproduced, leading to a significant underestimation of a viscosity or Schmidt number. Finally, the differences of the viscosity and long-time behavior of the VACF between MD and NMDPD systems implied the necessity of a more appropriate description for a one-to-one correspondence between a CG particle and a water cluster.
\end{abstract}

Keywords : Mori-Zwanzig projection operator, Genralized Langevin equation, Memory effect, Iterative Boltzmann inversion, Dissipative particle dynamics, Molecular dynamics

\section{1. 緒言}

分子動力学（Molecular dynamics, MD）法をはじめとした分子論的な数值計算手法は，ナノスケールの現象解析 に広く用いられている．MD は，系を構成する分子の特性に立脚した現象予測が可能であり，表面効果の顕在化 する微小流路（Hummer et al., 2001）や不均質な多成分系（Dror et al., 2012）等，構成則に基づく連続体としての 扱いが困難な現象に対しても適用できるという利点を持つ. 反面，個々の原子・分子の運動の詳細を陽に扱うた め，メソスケール以上の現象に適用寸る際には膨大な計算コストが生じる．また一方で，より実現象に近い不均 一系における非定常過程等を終始追跡するためには，その不均一性を包含できる程度の十分大きな系で，長時間 の計算を行う必要が生じる（Komarov et al., 2013）.

このような問題に取り組むにあたって，「粗視化」が一つの有効な手段となる．粗視化とは，図 1 に示すよう に，複数の原子をまとめて一つの粗視化粒子として扱うことにより，考慮すべき粒子数と相互作用数を低減する 方法である．粗視化の際に課題となるのは，微視的粒子群（クラスタ）を単一の粗視化粒子で表現することに伴 う情報の損失，即ち物性の再現性低下である．散逸粒子動力学（Dissipative particle dynamics, DPD）は，第二種摇

No.18-00193 [DOI:10.1299/transjsme.18-00193], J-STAGE Advance Publication date : 31 August, 2018

*1 正員, 東京大学 大学院工学系研究科（广113-8656 東京都文京区本郷 7-3-1）

*2 東京大学 大学院工学系研究科

*3 正員, フェロー, 東京大学 大学院工学系研究科

E-mail of corresponding author: kihara@fel.t.u-tokyo.ac.jp 

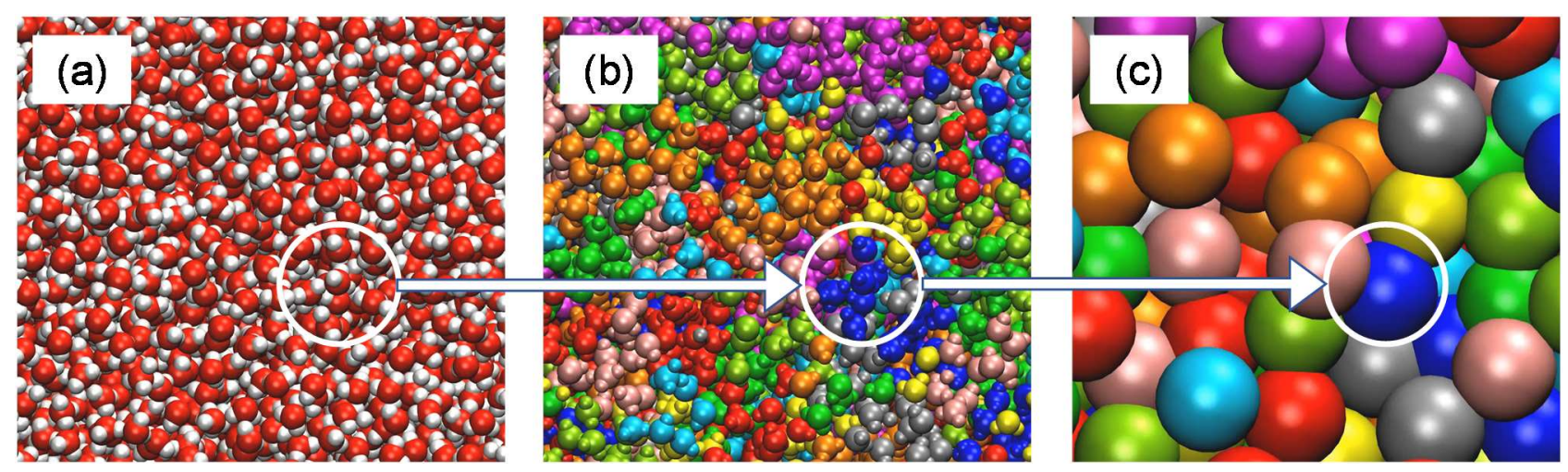

Fig. 1 (a) Water molecules in MD simulation, (b) clustered molecules tinted in 10 colors, and (c) the centers-of-mass (COMs) of clusters representing coarse-grained particles.

動散逸定理を満たすランダム力・散逸力を含む運動方程式を解くことで，粗視化による計算負荷の軽減と再現性 の向上との両立を目指している（Hoogerbrugge and Koelman, 1992; Español and Warren, 1995).

本研究でモデル化の対象とする液体状態の水分子は, 高分子溶液の溶媒等として工学的な用途が広い. 先行研 究においても，水の DPD モデル（Groot and Warren, 1997）を溶媒として用い，固体分散体の溶解度の $\mathrm{pH}$ 依存性 の検討（Sun et al.,2016）や，DNA 分子鎖の微小流路内における挙動の解析（Fan et al.,2006）等が行われている. ただし, 既存の DPD モデルの多くは, 単純な形状の相互作用関数を規定し, 等温圧縮率や拡散係数等, 注目寸る 物理量を再現するようにパラメータを規定している.ささに, 従来の DPD は, 摇動力の時間履歴を無視するマル コフ近似に基づいているため, 対象とする物理量以外（特に時間相関関数）の再現性については保証されない

(Groot and Warren, 1997; Groot and Rabone, 2001). 一方で, 粗視化粒子間の流体力学的相互作用の有無がブロック 共重合体の相分離構造に大きな影響を及ぼす（Groot et al., 1999）という報告や，微粒子の集積過程における微視 的な熱運動と巨視的相互作用との競合が結晶形成の可否を決定する（Marín et al., 2011）等の報告がされており, 粗視化粒子間の相互作用を精緻に構築する必要性が示唆されている.

そこで本研究では,粗視化粒子間の相互作用を水分子の MD シミュレーションからボトムアップ的に抽出する. 具体的には, Mori-Zwanzig 射影演算子法（Zwanzig, 1960; Mori, 1965）と Iterative Boltzmann inversion 法 (Reith et al., 2003; Ingolfsson et al., 2014）に基づき, 履歴効果を考慮した非マルコフ散逸粒子動力学（Non-Markovian DPD, NMDPD） モデル（Yoshimoto et al., 2013; Li et al., 2015; Yoshimoto et al., 2017）を構築する. さらに，水の NMDPD モデルの静的・動的特性を取得し，MD やマルコフ近似に基づく DPD と比較することで, MD 由来の相互作用や 履歴効果が粗視化モデルの特性に与える影響を検討する.

\section{2. 理 論}

\section{$2 \cdot 1$ Mori-Zwanzig 射影演算子法に基づく一般化 Langevin 方程式}

Mori-Zwanzig 射影演算子法は, 多自由度系から興味のある自由度を峻別するための方法である（Zwanzig, 1960; Mori, 1965). いま, $N_{\mathrm{t}}$ 個の微視的粒子で構成される系を考える. それらを $K$ 個のクラスタに分割し, 各クラスタ の重心の位置と運動量 $\left\{\mathbf{R}_{\mu}, \mathbf{P}_{\mu} ; \mu=1, \ldots, K\right\}$ を興味のある自由度とすると, クラスタ重心, 即ち粗視化粒子の運 動は以下の一般化 Langevin 方程式で記述される（Kinjo and Hyodo, 2007）.

$$
\frac{\mathrm{d} \mathbf{P}_{\mu}}{\mathrm{d} t}=\frac{1}{\beta} \frac{\partial}{\partial \mathbf{R}_{\mu}} \ln \omega(\mathbf{R})-\sum_{v=1}^{K} \int_{0}^{t} \mathrm{~d} s \beta\left\langle\left[\delta \mathbf{F}_{\mu}^{Q}(t-s)\right]\left[\delta \mathbf{F}_{v}^{Q}(0)\right]^{\mathrm{T}}\right\rangle \frac{\mathbf{P}_{\nu}(s)}{M_{v}}+\delta \mathbf{F}_{\mu}^{Q}(t)
$$

ここで， $k_{\mathrm{B}}$ を Boltzmann 定数， $T$ を絶対温度として， $\beta=\left(k_{\mathrm{B}} T\right)^{-1}, M_{v}$ はクラスタ $v$ 質量である. 式(1) の右辺 第 1 項は保存力, 第 2 項は摩擦に相当する散冕力, 第 3 項は微視的粒子の熱運動に起因する摇動力となっている. 
散逸力は, 摇動力の時間相関とクラスタの運動量の畳み込みで表されており, 第二種摇動散逸定理が満たされる. また，

$$
\omega(\mathbf{R})=\frac{\int \mathrm{d}^{N_{\mathrm{t}}} \hat{\mathbf{r}} \delta(\widehat{\mathbf{R}}-\mathbf{R}) \mathrm{e}^{-\beta U}}{\int \mathrm{d}^{N_{\mathrm{t}}} \hat{\mathbf{r}} \mathrm{e}^{-\beta U}}
$$

は, 粗視化配置空間上の点 $\mathbf{R}=\left\{\mathbf{R}_{\mu} ; \mu=1, \ldots, K\right\}$ に対応する微視的粒子の全配置に関する規格化分配関数である

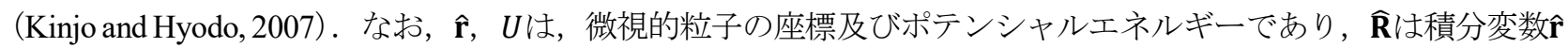
に対応した粗視化配置空間上の点である.

\section{$2 \cdot 2$ 非マルコフ散逸粒子動力学 (Non-Markovian dissipative particle dynamics, NMDPD)}

一般化 Langevin 方程式(1) の近似と離散化は, 先行研究（Yoshimoto et al., 2013）にならっている. 式(1) では, 保存力と散冕力はそれぞれ，全粗視化粒子の位置と運動量に依存しており，これらの多体相互作用を直接評価す ることは困難である. そこで, 各粗視化粒子に作用する力を, $\mathbf{F}_{\mu} \approx \sum_{\nu \neq \mu} \mathbf{F}_{\mu \nu}$ と近似することで, 二体間相互作用 の和で表現する. さらに, $\left\langle\left[\delta \mathbf{F}_{\mu \nu}^{Q}(t)\right]\left[\delta \mathbf{F}_{\mu \eta}^{Q}(0)\right]^{\mathrm{T}}\right\rangle_{\eta \neq \nu} \approx \mathbf{0}$ とし, 異なるぺア間の多体相関を無視すると, 式(1) は 次のように書き換えられる.

$$
\frac{\mathrm{d} \mathbf{P}_{\mu}}{\mathrm{d} t}=\sum_{\nu \neq \mu} \mathbf{F}_{\mu \nu}(t)=\sum_{\nu \neq \mu}\left[\left\langle\mathbf{F}_{\mu \nu}\right\rangle-\int_{0}^{t} \mathbf{K}_{\mu \nu}(t-s) \mathbf{V}_{\mu \nu}(s) \mathrm{d} s+\delta \mathbf{F}_{\mu \nu}^{Q}(t)\right]
$$

ここで， $\mathbf{F}_{\mu \nu}$ は粗視化粒子 $\mu, v$ 間に作用寸る瞬時の力, $\left\langle\mathbf{F}_{\mu \nu}\right\rangle$ は $\mathbf{F}_{\mu \nu}$ のアンサンブル平均, $\delta \mathbf{F}_{\mu \nu}^{\mathrm{Q}}$ は二体間摇動力, $\mathbf{V}_{\mu \nu}=\mathbf{V}_{\mu}-\mathbf{V}_{v}$ は粗視化粒子間の相対速度である. 二体間記憶核 $\mathbf{K}_{\mu \nu}$ は，2 階のテンソル

$$
\mathbf{K}_{\mu \nu}(t)=\beta\left\langle\left[\delta \mathbf{F}_{\mu \nu}^{\mathrm{Q}}(t)\right]\left[\delta \mathbf{F}_{\mu \nu}^{\mathrm{Q}}(0)\right]^{\mathrm{T}}\right\rangle
$$

で与えられ，第二種摇動散逸定理を満たす.なお， $\boldsymbol{\gamma} \equiv \int_{0}^{\infty} \mathbf{K}_{\mu \nu} \mathrm{d} t$ とし，式(4) の $\mathbf{K}_{\mu \nu}(t)$ が $2 \boldsymbol{\gamma} \delta(t)$ で近似できる場 合，マルコフ近似に基づくDPD の運動方程式が得られる（Lei et al., 2010）.

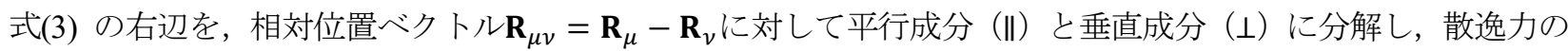
積分項を離散化すると，以下の NMDPD の運動方程式が得られる（Yoshimoto et al., 2013; Li et al., 2015）.

$$
\begin{array}{r}
\frac{\mathrm{d} \mathbf{P}_{\mu}}{\mathrm{d} t}=\sum_{\nu \neq \mu}\left[F^{\mathrm{C}}\left(R_{\mu \nu}\right) \mathbf{e}_{\mu \nu}(t)-\Delta t \sum_{n=0}^{N} \alpha_{n} \Gamma_{\mu \nu, n}^{\|}\left(R_{\mu \nu}(t-n \Delta t)\right) \mathbf{V}_{\mu \nu}^{\|}(t-n \Delta t)\right. \\
\left.-\Delta t \sum_{n=0}^{N} \alpha_{n} \Gamma_{\mu \nu, n}^{\perp}\left(R_{\mu \nu}(t-n \Delta t)\right) \mathbf{V}_{\mu \nu}^{\perp}(t-n \Delta t)+\delta \mathbf{F}_{\mu \nu}^{\mathrm{Q}}\right]
\end{array}
$$

ここで, $\Delta t$ は粗視化タイムステップ, $F^{\mathrm{C}}\left(R_{\mu \nu}\right)$ は保存力の振幅, $R_{\mu \nu}=\left|\mathbf{R}_{\mu \nu}\right|, \mathbf{e}_{\mu \nu}=\mathbf{R}_{\mu \nu} / R_{\mu \nu}, \alpha_{n}=1 / 2(n=$ $0, N)$ or $1(n=1, \ldots, N-1), \Gamma_{\mu \nu, n}^{\|, \perp}\left(R_{\mu \nu}\right)=K_{\mu \nu}^{\|, \perp}\left(R_{\mu \nu}, n \Delta t\right)$ である. なお, 二体間記憶核 $\mathbf{K}_{\mu \nu}(t)=K_{\mu \nu}^{\|}(t) \mathbf{e}_{\mu \nu} \mathbf{e}_{\mu \nu}^{\mathrm{T}}+$ $K_{\mu \nu}^{\perp}(t)\left(\mathbf{I}-\mathbf{e}_{\mu \nu} \mathbf{e}_{\mu \nu}^{\mathrm{T}}\right)$ の各成分 $K_{\mu \nu}^{\|, \perp}$ は, $t$ だけではなく $R_{\mu \nu}$ の関数にもなっている. 運動方程式(5) は, 有限時間 $N \Delta t$ の履歴効果を考慮した非マルコフ的描像の定式化となっている. 散冕力と摇動力は， $\mathbf{R}_{\mu \nu}$ に対して平行と垂直方 向の 2 成分を持つ（Junghans et al., 2008). 一方で, 保存力は粗視化粒子間に作用する合力のアンサンブル平均で あるため, 粒子間の動径方向成分のみを持つ. なお, 本来は粒子の相対配置 $\mathbf{R}_{\mu \nu}$ は時々刻々変化することから, よ 
り厳密には，それに応じて記憶核 $K_{\mu \nu}^{\|, \perp}\left(R_{\mu \nu}, t\right)$ も変化する．しかし，後述するように，本研究で考慮する履歴効果 の持続時間は十分に短いため, $\mathbf{R}_{\mu \nu}$ の変化の影響はごく小さく, 無視できるものとしている.

以上のように, NMDPD の運動方程式は，保存力，散冕力，摇動力の項によって構成されている．このうち， 散逸力と摇動力の間には式(4) で表される第二種摇動散逸定理が成り立つため, 記憶核が求まれば, 摇動力の適 切な形式も決まる。 そこで本研究では, 保存力と記憶核を MD シミュレーションからサンプリングし, NMDPD モデルを構築する.

\section{MD に基づく NMDPD モデルの構築}

\section{$3 \cdot 1 \mathrm{MD}$ の計算条件}

計算領域は, 全方向に周期境界条件が課された一辺 $134 \AA ̊$ の立方体セルで, 系内の水分子数は 80000 個である. MDにおける構造緩和は, 等間隔かつ等姿勢で配置した水分子の初期状態から, 以下の手順で実現した.まずNoséHoover 熱浴（Nosé, 1984; Hoover, 1985）により系の温度を 298 K に保持し，NVTアンサンブルにおいて 20 万ステ ップ計算する. その後, $N V E$ アンサンブルにおいて 80 万ステップの計算を行うことで, 系の温度は $298 \mathrm{~K}$, 圧力 は $9.0 \times 10^{5} \mathrm{~Pa}$ となり, 常温・常圧下の水に近いものとなった. 相互作用のカットオフ距離は $15 \AA$ A, 原子の位置と 速度のスナップショットは $5 \mathrm{fs}$ 毎にサンプリングする. 相互作用の抽出には, 300 万ステップ分のスナップショ ットを用いている. 本研究では, MD の計算コードにLAMMPS (Plimpton, 1995) を用い, タイムステップは $1 \mathrm{fs}$ とした.

ポテンシャルの計算では以下の Lennard-Jones (LJ) (12-6) ポテンシャルと Coulomb ポテンシャルを考慮する.

$$
\begin{aligned}
& V_{\mathrm{LJ}}\left(r_{i j}\right)=4 \varepsilon\left[\left(\frac{\sigma}{r_{i j}}\right)^{12}-\left(\frac{\sigma}{r_{i j}}\right)^{6}\right] \\
& \mathrm{V}_{\text {Coul }}\left(r_{i j}\right)=\frac{1}{4 \pi \varepsilon_{0}} \frac{q_{i} q_{j}}{r_{i j}}
\end{aligned}
$$

ここで, $r_{i j}$ は原子 $i, j$ 間の距離， $q_{i}$ は原子 $i$ の電荷， $\varepsilon_{0}$ は真空の誘電率である．なお，相互作用を考慮する原子の 組み合わせ及び LJ パラメータ $\varepsilon, \sigma$ 值は，SPC/E モデル（Berendsen et al., 1987）に準じたものとなっている. 減 衰が遅い Coulomb 相互作用の計算には，Ewald 法に代表されるような，長距離成分を逆格子空間で扱う手法が一 般的である. 本研究でも, MD シミュレーションにおける Coulomb 相互作用については, Particle-Particle ParticleMesh（PPPM）法によって計算している（Hockney and Eastwood, 1988). PPPM 法は Ewald 法に基づいており，長 距離相互作用を逆格子空間で計算する，またその際には，個々の原子が持つ点電荷ではなく，格子状に区切った 空間内の電荷密度を用いており, Ewald 法以上に計算負荷が軽減されている. 一方で，この手法では，MD 系に おける原子間相互作用と粗視化粒子の二体間相互作用の算出過程を対応させることができない，これは，PPPM 法では，遠方の電荷の影響を点電荷ではなく電荷分布からの寄与として扱い，二体間相互作用の形式をとらない ためである，そこで本研究では，後述するように，MD シミュレーション後のスナップショットからクラスタ間 に作用する力を評価する際には, Coulomb 相互作用については式(6b) をそのまま計算している.

なお，事前検討として，Fennell ら（Fennell and Gezelter, 2006）の提案した手法を用いたモデルの構築も試みた. この手法では, 静電相互作用の遮蔽効果を仮定して静電ポテンシャルの減衰を強めることにより, 2 原子間の直 接計算のみで Coulomb 相互作用を求められる. しかし急峻な関数形に伴うノイズとオフセットの影響により, 妥 当な記憶核のサンプリングが不可能であったため, 本研究では前述の手法でのモデル構築を行っている.

\section{$3 \cdot 2$ 粗視化粒子の定義}

平衡状態にある $\mathrm{MD}$ 系のスナップショットにおいて, 空間的に近接する $N_{\mathrm{C}}=10$ 個の水分子を仮想的にクラス タとして定義し，このクラスタを粗視化粒子とみなすことで，それらに働く保存力及び記憶核を抽出した. 図 2 に示すように, クラスタ $\mu$ の慣性半径を 


$$
R_{\mathrm{g}, \mu}=\sqrt{\frac{1}{N_{\mathrm{c}}} \sum_{i=1}^{N_{\mathrm{c}}}\left(\mathbf{r}_{i}^{\mu}-\mathbf{R}_{\mu}\right)^{2}}
$$

と定義する. ここで, $\mathbf{r}_{i}^{\mu}$ はクラスタ $\mu$ に含まれる水分子 $i$ の位置である. 全てのクラスタについての平均慣性半径 $\left\langle R_{\mathrm{g}, \mu}\right\rangle$ が最小となるように，クラスタ間で水分子の所属の交換を行う.1 1 ステップ目のスナップショットにおいて 所属を最適化した後, 次のステップでは分子の運動により最適なクラスタ定義が変化するため, 前回の定義を初 期条件として用いて，再度水分子の所属を交換し最適化を行う。この手順をステップ毎に繰り返し，クラスタ構 造が緩和するまでに 50 万ステップ分のクラスタを定義していった. 構造緩和後の $\left\langle R_{\mathrm{g}, \mu}\right\rangle$ は $3.30 \AA$ に収束し, クラ スタ重心の動径分布関数（Radial distribution function, RDF）は図 3(a) に示されるようになった. また所属の更新 を行わない場合に，一度定義されたクラスタの慣性半径が時間経過とともに大きくなった. クラスタの平均慣性 半径 $\left\langle R_{\mathrm{g}, \mu}\right\rangle$ の推移を図 3(b) に示寸.この図から，クラスタが $250 \mathrm{fs}$ 経過後に $3 \%$ ほど拡大し，10 ps 後には $50 \%$ 程 度桩大寸ることが分かる. したがって, 数 $\mathrm{ps}$ 以上の比較的長時間にわたる物理量の相関については, 有意義な步 ンプリングが難しいと考えられる.

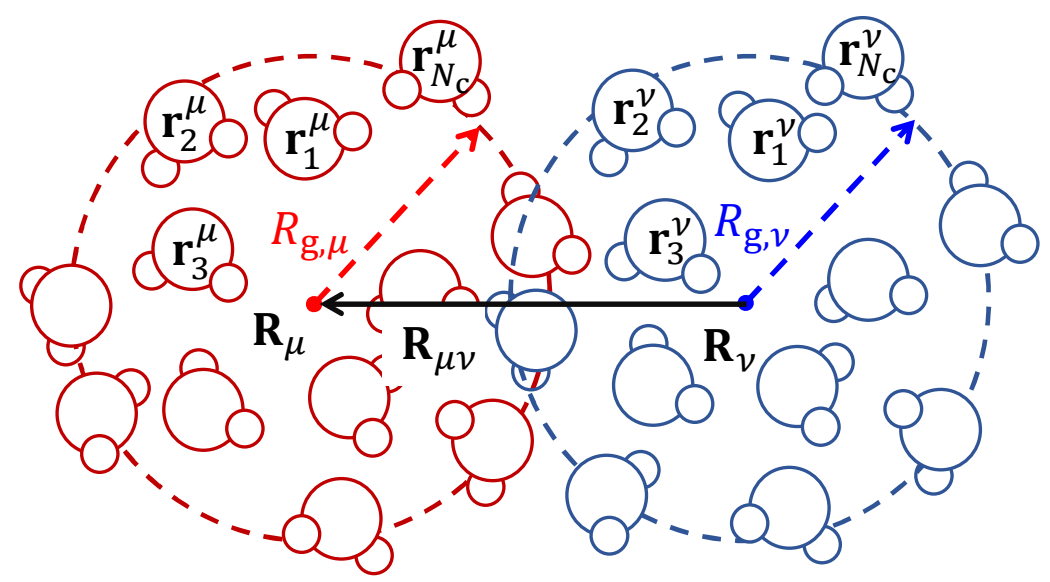

Fig. 2 Schematic of clusters each of which contains $N_{\mathrm{c}}$ molecules. The assignments of the molecules are swapped such that the average radius of gyration of the clusters becomes minimal.

(a)

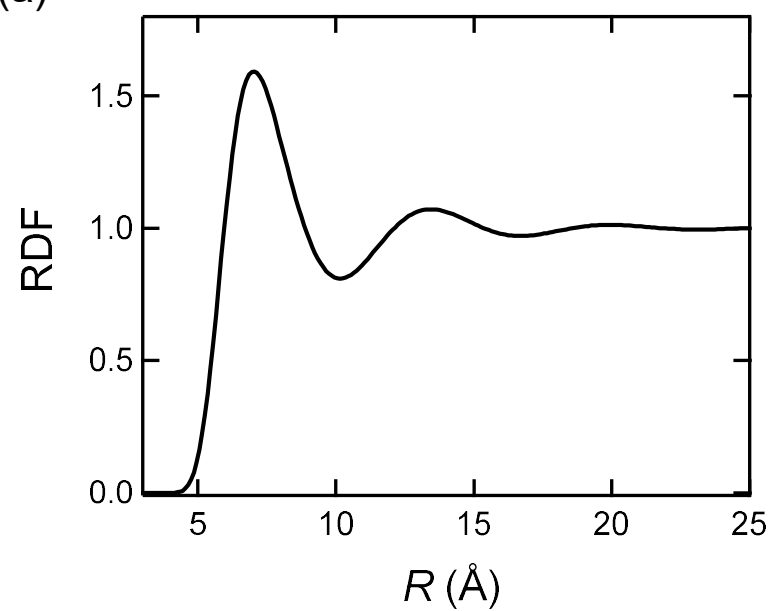

(b)

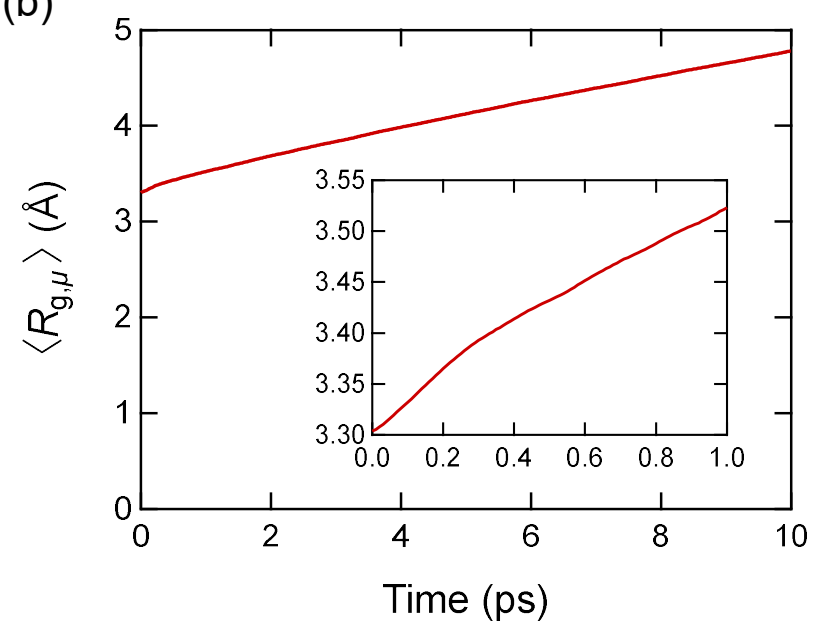

Fig. 3 (a) Radial distribution function (RDF) of the cluster COMs in the MD system and (b) the time variation in the mean radius of gyration of the clusters when the assignments of the molecules remain unchanged. The inset of the right figure is an enlarged view. The first peak of the RDF appears at $R \approx 7 \AA$. 


\section{$3 \cdot 3$ 粗視化二体ポテンシャルの抽出と補正}

保存力を求めるにはまず，ある瞬間に相対距離 $R_{\mu \nu}$ を隔てて位置する 2 クラスタ間に働く合力，即ち式(3) にお ける $\mathbf{F}_{\mu \nu}$ を求める必要がある. 保存力は, 合力 $\mathbf{F}_{\mu \nu}$ のアンサンブル平均として, $\left\langle\mathbf{F}_{\mu \nu}\right\rangle=F^{\mathrm{C}}\left(R_{\mu \nu}\right) \mathbf{e}_{\mu \nu}$ より得られる. クラスタ $\mu, v$ 間の相互作用を抽出寸る際には, 各クラスタに所属寸る 2 つの原子 $i, j$ 間の相互作用を式(6) に従 って足し合わせていく．なお相互作用をサンプリングする際の空間解像度は 0.1 Åとしている.

上記の手順で取得した保存力から求まる粗視化二体ポテンシャルは, 図4(a) の一点鎖線のようになる.このポ テンシャルを用いた NMDPD シミュレーションを行った結果，系の圧力の著しい低下と，それに伴う相分離の発 生が確認された. また, 粗視化粒子の RDF についても, 図 4(b) の一点鎖線に示すように, 実線で示した元の MD クラスタの RDF から乘離しており, 静的な構造を再現できていない. これらの理由については今後も検討が必要 であるが, 主な要因としては，一般化 Langevin 方程式(1) で多体間相互作用として与えられた各相互作用を， 2 体 間力の和で置換するという近似を行ったことが影響していると考えられる. また 10 個程度の水分子から構成さ れる粗視化粒子では形状の非球対称性が無視できず, 球対称を仮定したモデル化が不適切なことも要因の一つと なっている可能性がある.

上記の問題を受けて, 多体効果を実効的に組み込み, RDF と圧力を MD シミュレーションの結果に合わせるべ <, Iterative Boltzmann inversion (IBI) 法（Reith et al., 2003; Ingolfsson et al., 2014）により粗視化二体ポテンシャル を補正した．IBI 法は，目標とする動径分布関数 $g_{\mathrm{ref}}(R)$ を再現するように，ポテンシャルを反復計算により修正 していく手法であり, 以下の手順を踏む. (i) $i$ 回目の修正後のポテンシャル $V_{i}^{\mathrm{CG}}(R)$ を用いて, 元の系と同条件下 で粗視化 MD（Coarse-grained MD, CGMD）による緩和計算を行う. (ii) 緩和した系から, 動径分布関数 $g_{i}(R)$ を取 得する. (iii) 得られた $g_{i}(R)$ と目標とする $g_{\mathrm{ref}}(R)$ を用いて, 式(8) の右辺第 2 項に示寸補正項を算出し, 修正後の ポテンシャル $V_{i+1}^{\mathrm{CG}}(R)$ を求める.

$$
V_{i+1}^{\mathrm{CG}}(R)=V_{i}^{\mathrm{CG}}(R)-k_{\mathrm{B}} T \ln \left[\frac{g_{i}(R)}{g_{\mathrm{ref}}(R)}\right]
$$

(iv) 上記(i) から(iii) の手順を, RDF と圧力が目標值に収束するまで反復する. 本研究では, IBIによるポテンシ ヤル補正に，フリーソフトウェアである VOTCA（Rühle etal., 2009）を用いた. IBI の各ステップiでは CGMD の 時間刻みを $2 \mathrm{fs}$ とし， $60 \mathrm{ps}$ の緩和計算の後にサンプリング計算を $240 \mathrm{ps}$ 行い，RDF 計算した．ポテンシャル 補正の際のカットオフは，IBI 修正前のもの（図4(a) の一点鎖線）に合わせ，20 ̊ とした。 なお CGMD系の圧 カについては全原子 MD と同様に, 運動エネルギーと virial から計算した. また IBI によって RDF が目標の $g_{\mathrm{ref}}(R)$
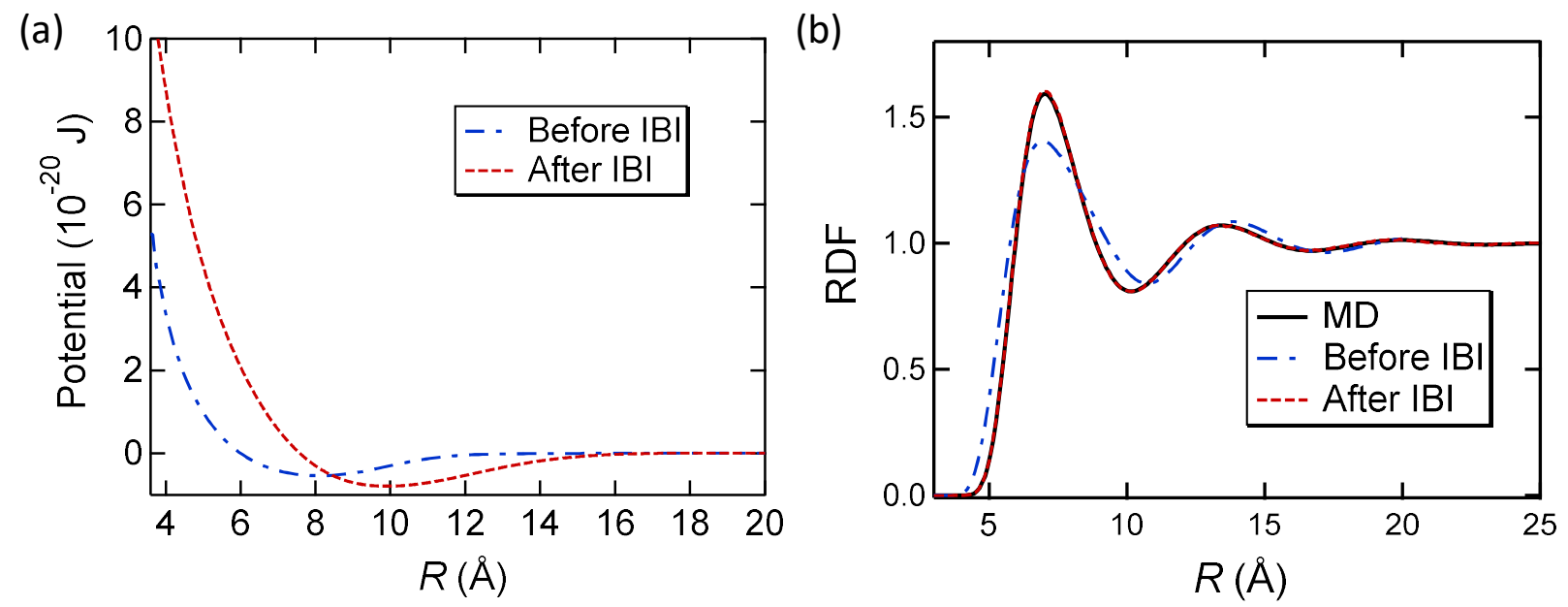

Fig. 4 (a) Inter-cluster potentials and (b) RDFs in the MD and CGMD systems before and after the IBI correction. The post-IBI potential involves a longer-range repulsive core than the pre-IBI potential, rendering the post-IBI RDF and pressure close to the MD counterparts. 
に十分収束した後も，さらにポテンシャルの更新を繰り返し，圧力が最も MD の值に近くなるポテンシャルを採 用した. 本研究では, IBIによるポテンシャル更新を計 338 回行った.

補正後のポテンシャルと RDF を図 4(a),(b) に破線で示す。このように，IBI 補正によって，ポテンシャル曲線 によって示される粗視化粒子間の平衡距離は大きくなり，その結果として CGMD系の RDF は MD と一致するよ うになった. また, CGMD 系の圧力は, $-2.8 \times 10^{7} \mathrm{~Pa}$ から $3.2 \times 10^{5} \mathrm{~Pa}$ へと上昇し, MD系の圧力と概正致した.

\section{$3 \cdot 4$ 二体間記憶核及び摩擦係数の抽出}

二体間記憶核 $\mathbf{K}_{\mu \nu}$ を取得する際には, まず式(3) におけるクラスタ $\mu, v$ 間の合力 $\mathbf{F}_{\mu \nu}$ から保存力を引き, 以下の 式で定義される力のゆらぎ $\delta \mathbf{F}_{\mu \nu}$ を求める.

$$
\delta \mathbf{F}_{\mu \nu}(t) \equiv \mathbf{F}_{\mu \nu}-\left\langle\mathbf{F}_{\mu \nu}\right\rangle=-\int_{0}^{t} \mathbf{K}_{\mu \nu}(t-s) \mathbf{V}_{\mu \nu}(s) \mathrm{d} s+\delta \mathbf{F}_{\mu \nu}^{\mathrm{Q}}(t)
$$

なお，ここで用いる保存力は，前節で求めた IBI 補正後の力ではなく，合力の平均值としての性質を持つ補正前 のものである. $\delta \mathbf{F}_{\mu \nu}$ をこのように定義することで， $\delta \mathbf{F}_{\mu \nu}$ のアンサンブル平均が 0 となることが保証される. 式( $(9)$ の両辺に右側から $\mathbf{V}_{\mu \nu}^{\mathrm{T}}(0)$ を乗じ, アンサンブル平均をとると， $\left\langle\delta \mathbf{F}_{\mu \nu}^{\mathrm{Q}}(t) \mathbf{V}_{\mu \nu}^{\mathrm{T}}(0)\right\rangle=\mathbf{0}$ に注意して (Yoshimoto et al., 2017）, 以下の第一種 Volterra積分方程式が得られる.

$$
\left\langle\delta \mathbf{F}_{\mu \nu}(t) \mathbf{V}_{\mu \nu}^{\mathrm{T}}(0)\right\rangle=-\int_{0}^{t} \mathbf{K}_{\mu \nu}(t-s)\left\langle\mathbf{V}_{\mu \nu}(s) \mathbf{V}_{\mu \nu}^{\mathrm{T}}(0)\right\rangle \mathrm{d} s
$$

上式において, $\left\langle\delta \mathbf{F}_{\mu \nu}(t) \mathbf{V}_{\mu \nu}^{\mathrm{T}}(0)\right\rangle$ と $\left\langle\mathbf{V}_{\mu \nu}(t) \mathbf{V}_{\mu \nu}^{\mathrm{T}}(0)\right\rangle$ は, MD シミュレーションから直接計算できる. 従って, 式(10) を逆畳み込み寸ることで, 記憶核 $\mathbf{K}_{\mu \nu}(t)$ を求められる. 実際に式(10) から記憶核を求める際には, 式(5) に対応 するように, $\mathbf{K}_{\mu \nu}(t)=K_{\mu \nu}^{\|}(t) \mathbf{e}_{\mu \nu} \mathbf{e}_{\mu \nu}^{\mathrm{T}}+K_{\mu \nu}^{\perp}(t)\left(\mathbf{I}-\mathbf{e}_{\mu \nu} \mathbf{e}_{\mu \nu}^{\mathrm{T}}\right)$ とし, 動径平行方向と垂直方向に分けて計算する.

また, 時間相関関数 $\left\langle\delta \mathbf{F}_{\mu \nu}(t) \mathbf{V}_{\mu \nu}^{\mathrm{T}}(0)\right\rangle,\left\langle\mathbf{V}_{\mu \nu}(t) \mathbf{V}_{\mu \nu}^{\mathrm{T}}(0)\right\rangle$ の計算の際は, それらの不連続な時間変化を避けるために

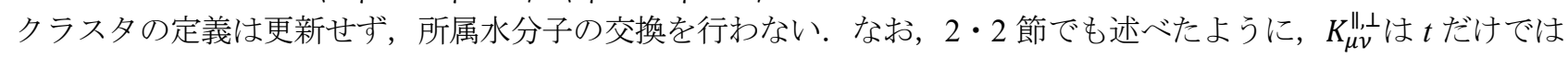
なく $R_{\mu \nu}$ の関数にもなっている.

(a)

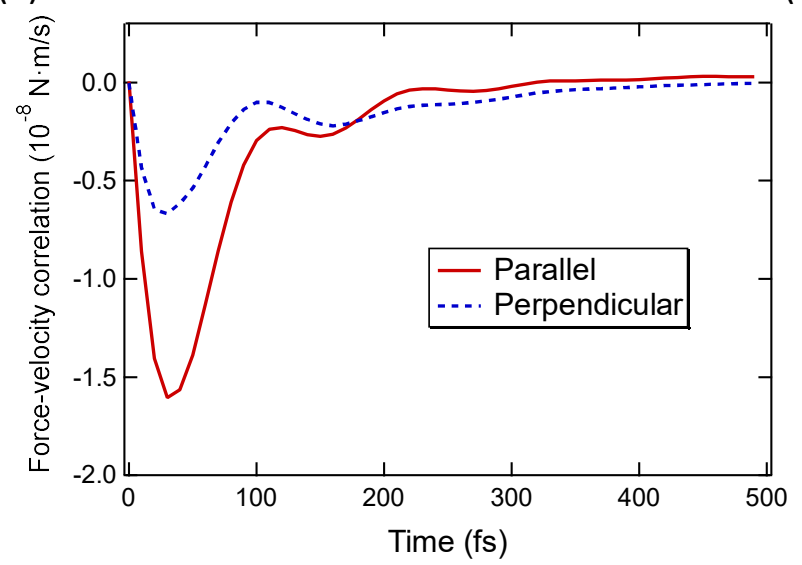

(b)

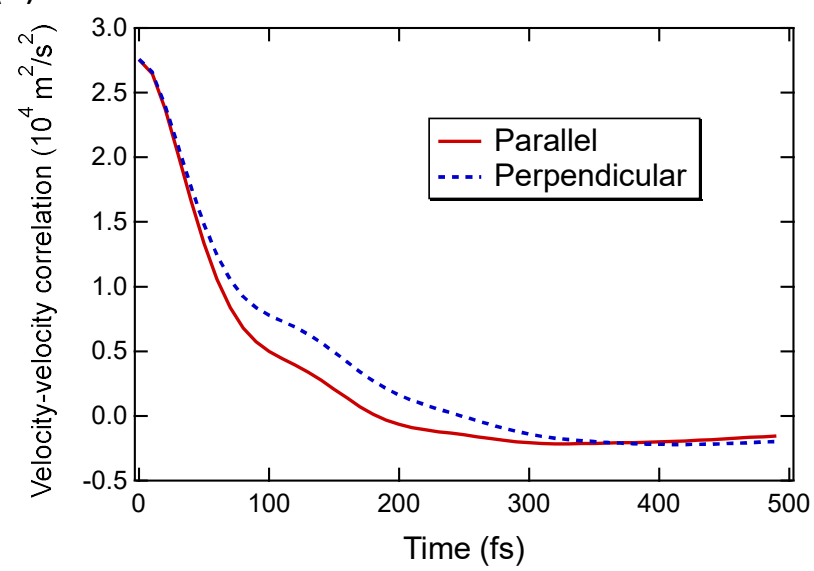

Fig. 5 (a) Force-velocity correlations and (b) velocity-velocity correlations for $R_{\mu \nu}=7 \AA$, where the RDF of the MD clusters approximately takes on a maximal value as shown in Fig. 3(a). The parallel components are defined as $\left\langle\delta \mathbf{F}_{\mu \nu}^{\|}(t) \cdot \mathbf{V}_{\mu \nu}^{\|}(0)\right\rangle$ and $\left\langle\mathbf{V}_{\mu \nu}^{\|}(t) \cdot \mathbf{V}_{\mu \nu}^{\|}(0)\right\rangle$ while the perpendicular components are $\frac{1}{2}\left\langle\delta \mathbf{F}_{\mu \nu}^{\perp}(t) \cdot \mathbf{V}_{\mu \nu}^{\perp}(0)\right\rangle$ and $\frac{1}{2}\left\langle\mathbf{V}_{\mu \nu}^{\perp}(t) \cdot \mathbf{V}_{\mu \nu}^{\perp}(0)\right\rangle$. 


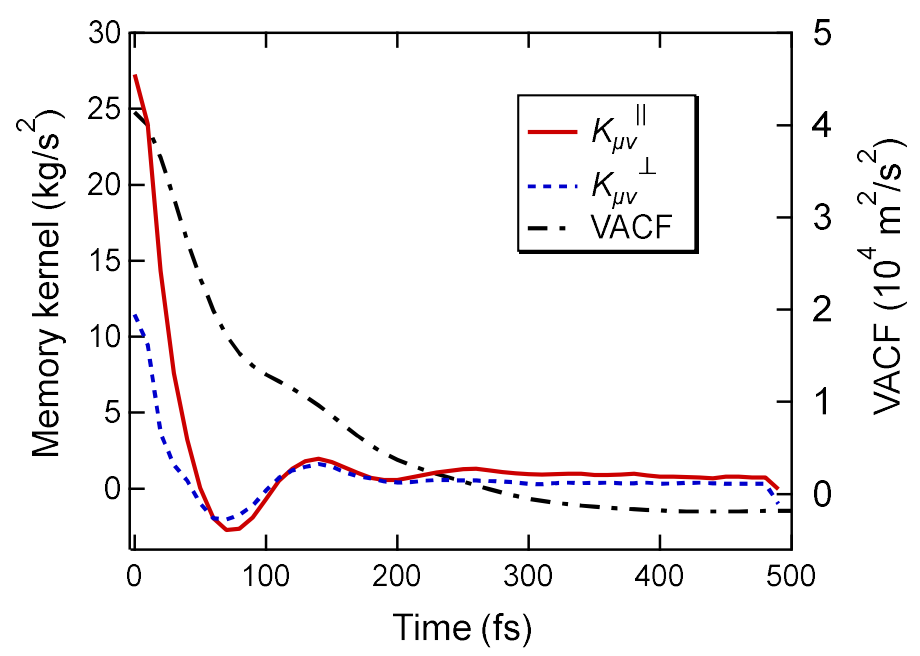

Fig. 6 Memory kernels for $R_{\mu \nu}=7 \AA$ obtained via Eq. (10). The velocity autocorrelation function (VACF) of the cluster COMs is also displayed as a measure of time scale separation. The memory kernels and VACF have comparable time scales, implying a nonMarkovian nature of the CG system.

図 5 に, $R_{\mu \nu}=7 \AA$ 啺合について, 時間相関関数 $\left\langle\delta \mathbf{F}_{\mu \nu}(t) \mathbf{V}_{\mu \nu}^{\mathrm{T}}(0)\right\rangle,\left\langle\mathbf{V}_{\mu \nu}(t) \mathbf{V}_{\mu \nu}^{\mathrm{T}}(0)\right\rangle$ の各成分を示寸. また図 6 に は，これらの時間相関関数と式(10) を用いて取得した記憶核を示す.なお，図 6 における一点鎖線は, MD ク スタの速度自己相関関数（Velocity autocorrelation function, VACF）を示している. VACF は，粗視化粒子の運動の 時間スケールを特徴づける物理量である. 図 6 より, 記憶核とVACF が同程度の特性時間を有していることから, マルコフ近似は不適切であり，履歴効果を考慮する必要があると示唆される.

図 6 における記憶核の減衰時間から，履歴を考慮する時間については $250 \mathrm{fs}$ と定めている. 先行する研究にお いて, 10 個の $\mathrm{Ar}$ 原子を粗視化したクラスタについて同様の手順を施した結果, 記憶核の減衰時間は $1 \mathrm{ps}$ 程度と, 水分子より長くなることが報告されている（Yoshimoto et al., 2017）。これは, Ar 原子に比べて水分子の質量が小 さく運動が俊敏であることに加え, 非対称な水分子の形状がクラスタの内部自由度を増加させていることに起因 すると考えられる.

(a)

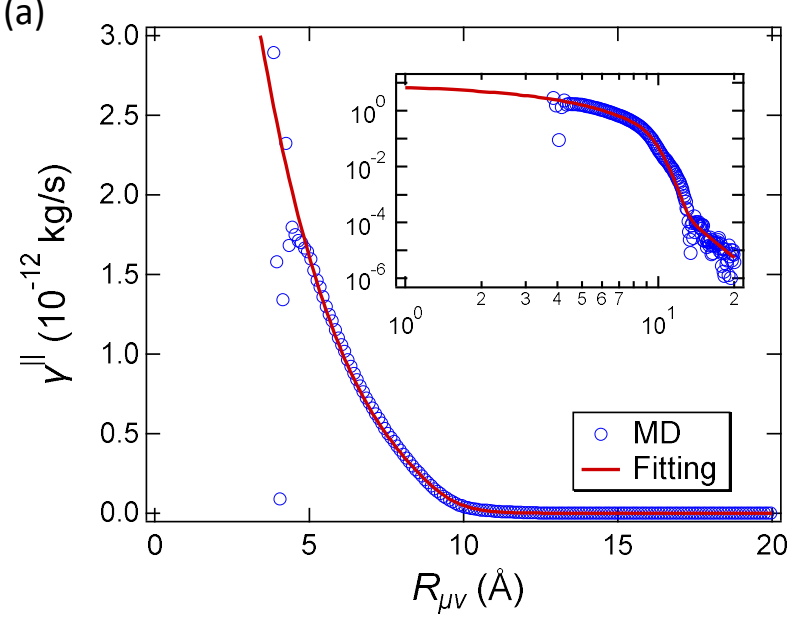

(b)

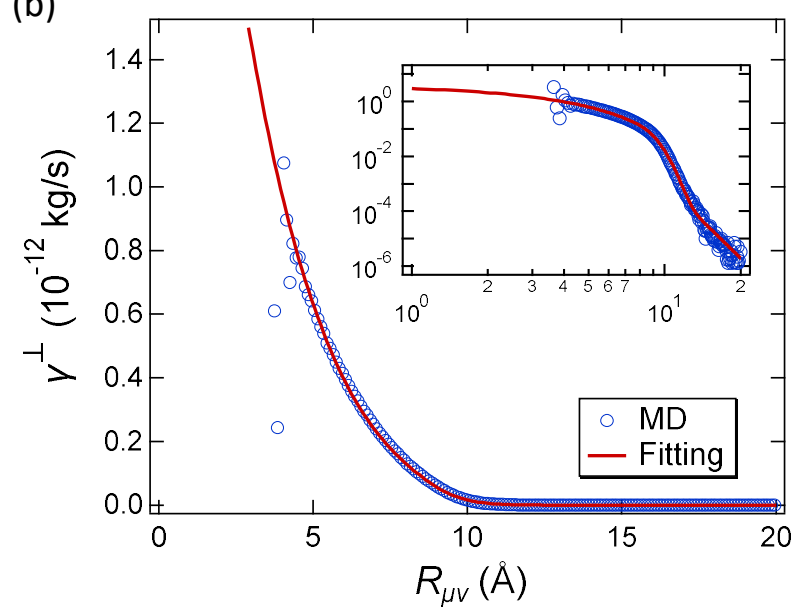

Fig. 7 Friction coefficients for (a) the radial direction and (b) the perpendicular direction. The shorter inter-cluster separation gives rise to the stronger frictional force. The insets show global views of the fitting functions, indicating algebraically decaying long-tails of the friction coefficients. 
次に，二体間記憶核に基づき，粗視化粒子間の摩擦係数を以下のように定義する.

$$
\gamma^{\|, \perp}\left(R_{\mu \nu}\right) \equiv \int_{0}^{t_{c}} K_{\mu \nu}^{\|, \perp}\left(R_{\mu \nu}, t\right) \mathrm{d} t
$$

ここで, 積分の上限は $t_{\mathrm{c}}=250 \mathrm{fs}$ である. 式(11) から求まる摩擦係数（図 7) に対して, 以下の関数をフィッティ ングする (Yoshimoto et al., 2017).

$$
\begin{aligned}
& \gamma^{\|, \perp}\left(R_{\mu \nu}\right)=(1-\alpha) \gamma_{\text {main }}\left(R_{\mu \nu}\right)+\alpha \gamma_{\text {tail }}\left(R_{\mu \nu}\right) \\
& \gamma_{\text {main }}\left(R_{\mu \nu}\right)=\left\{\begin{array}{cc}
\Lambda\left(1-\frac{R_{\mu \nu}}{R_{\mathrm{f} 1}}\right)^{s_{1}} & \left(0 \leq R_{\mu \nu}<R_{\mathrm{f} 1}\right) \\
0 & \left(R_{\mathrm{f} 1} \leq R_{\mu \nu}\right)
\end{array}\right. \\
& \gamma_{\text {tail }}\left(R_{\mu \nu}\right)=\left\{\begin{array}{cc}
\eta\left(\frac{R_{\mu \nu}}{R_{\mathrm{p}}}\right)^{-s_{2}} & \left(0 \leq R_{\mu \nu}<R_{\mathrm{f} 2}\right) \\
0 & \left(R_{\mathrm{f} 2} \leq R_{\mu \nu}\right)
\end{array}\right. \\
& \alpha=\exp \left[-\chi\left(1-\frac{R_{\mu \nu}}{R_{\mathrm{f} 2}}\right)^{s_{3}}\right]
\end{aligned}
$$

ここで, $\eta=4^{-5} \mathrm{~kg} / \mathrm{s}, R_{\mathrm{p}}=10 \AA \mathrm{A}, \chi=900, s_{3}=12$ である. 残りのパラメータ $\Lambda, R_{\mathrm{f} 1}, s_{1}, s_{2}, R_{\mathrm{f} 2}$ をフィッティングに よって定める. 式(12b) は, 図 7 の normal-normal プロットにおいて大域的に変化する成分を表している. 従来の DPD では $s_{1}=2$ であったのに対し, 本研究では動径方向及び動径垂直方向について, $s_{1}=4.9,5.3$ (表 1,2） となっ ており, 近距離で摩擦力がより急峻に増加する様式となっている. また, 摩擦係数の long-tail が長時間の拡散挙 動に多少の影響を及ぼすと考えられるため，遠方で代数的に減衰する long-tail を再現するために式(12c) を導入 した (図 7 の挿入図). なお, MD データのうち, フィッティングをかけたデータの範囲は, 動径平行方向が4.5 $15 \AA$ ，動径垂直方向が5 - $20 \AA$ であり，近距離でのデータはフィッティング区間から除外している. これは，図 4(b) の動径分布関数から読み取れるように，クラスタ同士の極端な接近がほとんど生じず，サンプリング数が不 十分であり,データの信頼性が低いためである. 以上のように, 摩擦係数の関数化により得られたパラメータを, 動径方向と動径垂直方向について，それぞれ表 1,2 にまとめる.

\section{$3 \cdot 5$ 二体間記憶核のモデリング}

本研究では，モデルの実装にあたって，二体間記憶核のノイズとオフセットを除去するために，記憶核の動径 平行方向と垂直方向の成分 $K_{\mu \nu}^{\|, \perp}\left(R_{\mu \nu}, t\right)$ に対するフィッティング関数を用意する. 以下のように，記憶核を時間 と距離を変数とする関数の積で表現する.

$$
K_{\mu \nu}^{\|, \perp}\left(R_{\mu \nu}, t\right) \approx \Phi^{\|, \perp}\left(R_{\mu \nu}\right) \theta^{\|, \perp}(t)
$$

ここで, $\theta^{\|, \perp}(0)=1$ である. 以下のように，記憶核の時間依存成分 $\theta^{\|, \perp}(t)$ を指数関数的に減衰する振動子の線形 和で近似する.

$$
\theta^{\|, \perp}(t) \approx \sum_{i=1}^{4} \kappa_{i} \cdot e^{-\frac{t}{\tau_{i}}} \cdot \cos \left(\omega_{i} t-\varphi_{i}\right)
$$

$\kappa_{i}, \tau_{i}, \omega_{i}, \varphi_{i}$ をフィッティングパラメータとし， Nelder-Mead 法（Nelder and Mead, 1965）を用いて MD デー 
Table 1 Fitting parameters for $\gamma^{\|}\left(R_{\mu \nu}\right)$ in Eq. (12).

\begin{tabular}{ccccc}
\hline \hline$\Lambda(\mathrm{kg} / \mathrm{s})$ & $s_{1}$ & $s_{2}$ & $R_{\mathrm{f1}}(\AA)$ & $R_{\mathrm{f} 2}(\AA)$ \\
\hline $9.23 \times 10^{-12}$ & 4.9 & 7.5 & 16.7 & 22 \\
\hline
\end{tabular}

Table 2 Fitting parameters for $\gamma^{\perp}\left(R_{\mu \nu}\right)$ in Eq. (12).

\begin{tabular}{ccccc}
\hline \hline$\Lambda(\mathrm{kg} / \mathrm{s})$ & $s_{1}$ & $s_{2}$ & $R_{\mathrm{fl}}(\AA)$ & $R_{\mathrm{f} 2}(\AA)$ \\
\hline $4.11 \times 10^{-12}$ & 5.3 & 9 & 16.8 & 22 \\
\hline
\end{tabular}

タに対してフィッティングを行った結果を図 8 に示す.フィッティングの対象データとして, 動径平行方向につ いて $R_{\mu \nu}=7 \AA$ A, 動径垂直方向について $R_{\mu \nu}=6.8 \AA ̊$ のものを用いた. 動径平行方向は, MDデータを式(14)によっ てよく再現できている，動径垂直方向についても，目標值の起伏の乱れからずれはあるものの，その概形を十分 にとらえたフィッティングを実現した. 以上のように記憶核の時間依存成分を関数化して得られたパラメータを, 動径方向について表 3 に, 動径垂直方向については表 4 にまとめる.

さらに，式(11),(13) に従い，記憶核の距離依存成分を以下のように計算できる.

$$
\Phi^{\|, \perp}\left(R_{\mu v}\right)=\frac{\gamma^{\|, \perp}\left(R_{\mu v}\right)}{\int_{0}^{t_{c}} \theta^{\|, \perp}(t) \mathrm{d} t}
$$

(a)

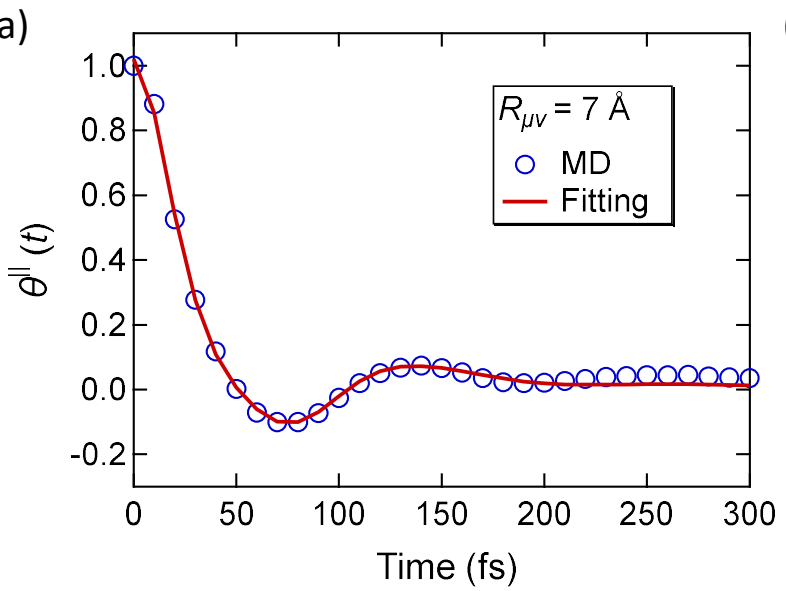

(b)

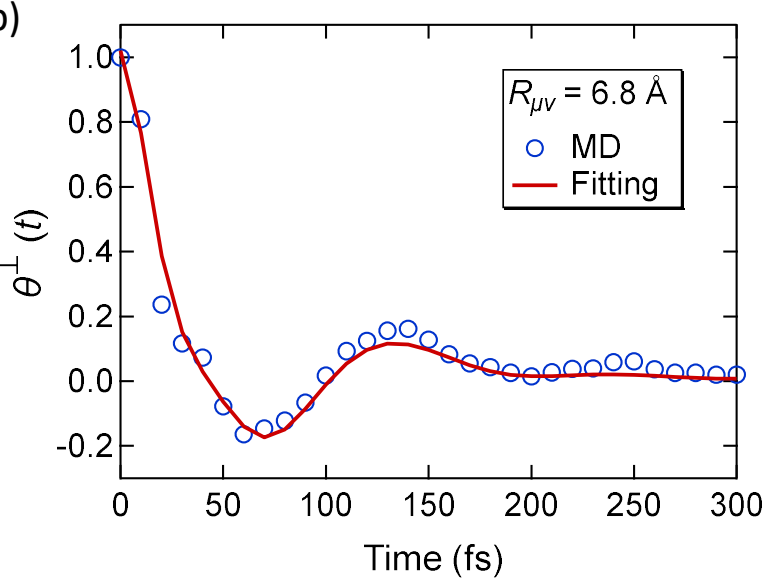

Fig. 8 Time-dependent parts of the memory kernels (a) parallel to $\mathbf{R}_{\mu \nu}, \theta^{\|}(t)$, and (b) perpendicular to $\mathbf{R}_{\mu \nu}, \theta^{\perp}(t)$. The MD counterparts in the parallel and perpendicular directions are shown with circular markers for $R_{\mu \nu}=7 \AA$ and $6.8 \AA$.

Table 3 Fitting parameters for $\theta^{\|}(t)$ in Eq. (14).

\begin{tabular}{c|c|c|c|c}
\hline \hline$i$ & 1 & 2 & 3 & 4 \\
\hline$\kappa_{i}$ & $8.63 \times 10^{-1}$ & $4.14 \times 10^{-1}$ & $5.01 \times 10^{-3}$ & $2.03 \times 10^{-1}$ \\
$\tau_{i}(\mathrm{~s})$ & $4.60 \times 10^{-14}$ & $1.00 \times 10^{-13}$ & $1.39 \times 10^{-14}$ & $2.88 \times 10^{-14}$ \\
$\omega_{i}(1 / \mathrm{s})$ & $4.46 \times 10^{13}$ & $1.60 \times 10^{12}$ & $2.37 \times 10^{13}$ & $1.04 \times 10^{14}$ \\
$\varphi_{i}$ & $4.53 \times 10^{-1}$ & 1.41 & 1.25 & $3.20 \times 10^{-1}$ \\
\hline
\end{tabular}


Table 4 Fitting parameters for $\theta^{\perp}(t)$ in Eq. (14).

\begin{tabular}{c|c|c|c|c}
\hline \hline$i$ & 1 & 2 & 3 & 4 \\
\hline$\kappa_{i}$ & $2.69 \times 10^{-1}$ & $2.62 \times 10^{-1}$ & $4.09 \times 10^{-1}$ & $4.81 \times 10^{-1}$ \\
$\tau_{i}(\mathrm{~s})$ & $1.10 \times 10^{-13}$ & $9.84 \times 10^{-14}$ & $8.28 \times 10^{-14}$ & $1.94 \times 10^{-14}$ \\
$\omega_{i}(1 / \mathrm{s})$ & $2.69 \times 10^{12}$ & $3.80 \times 10^{13}$ & $5.09 \times 10^{13}$ & $1.14 \times 10^{14}$ \\
$\varphi_{i}$ & 1.28 & $2.61 \times 10^{-1}$ & $2.33 \times 10^{-1}$ & $4.24 \times 10^{-1}$ \\
\hline
\end{tabular}

上式のように $\Phi^{\| \prime, \perp}\left(R_{\mu \nu}\right)$ を定めることで，記憶核の積分値を正確に粗視化シミュレーションに反映させることが 可能である.

また，摇動力に記憶核の時間依存成分の有色性を付与するため，有限インパルス応答（Finite impulse response, FIR）フィルタを用いる（Yoshimoto et al., 2013）。 $k$ を動径に平行な方向（l）及び垂直な 2 方向 $\left(\perp_{1}, \perp_{2}\right)$ を示す 変数とする. ただし, 3 方向 $\left(\|, \perp_{1}, \perp_{2}\right)$ は互いに直交し, クラスタのペア毎に局所座標系 $\left(\mathbf{e}_{\|}, \mathbf{e}_{\perp_{1}}, \mathbf{e}_{\perp_{2}}\right)$ を張るも のとする.このとき，各方向の摇動力を，

$$
\delta F_{\mu \nu}^{Q, k}(t)=\sum_{n=0}^{N} a_{n}^{k}\left(R_{\mu \nu}(t-n \Delta t)\right) \Theta_{\mu \nu}^{k}(t-n \Delta t)
$$

として与える.ここで, $\Theta_{\mu \nu}^{k}$ はガウス性白色雑音, $a_{n}^{k}$ は FIR フィルタのタップ係数, $N$ はフィルタ次数である. 式(16) は，時間相関のない白色雑音にタップ係数を乗じて畳夕込むことで，有限時間 $N \Delta t$ の履歴性を有する摇動 力を表現している. 動径垂直方向 $\left(\perp_{1}, \perp_{2}\right)$ の摇動力の等方性及びガウス性白色雑音の性質から,

$$
\begin{aligned}
\left\langle\delta \mathbf{F}_{\mu \nu}^{Q, \|}(l \Delta t) \cdot \delta \mathbf{F}_{\mu \nu}^{Q, \|}(0)\right\rangle= & \frac{1}{\beta} K_{\mu \nu}^{\|}(l \Delta t)=\frac{1}{\beta} \Phi^{\|}\left(R_{\mu \nu}\right) \theta^{\|}(l \Delta t)=\sum_{n=0}^{N-l} a_{n+l}^{\|}\left(R_{\mu \nu}\right) a_{n}^{\|}\left(R_{\mu \nu}\right) \\
\frac{1}{2}\left\langle\delta \mathbf{F}_{\mu \nu}^{Q, \perp}(l \Delta t) \cdot \delta \mathbf{F}_{\mu \nu}^{Q, \perp}(0)\right\rangle= & \frac{1}{\beta} K_{\mu \nu}^{\perp}(l \Delta t) \\
& =\frac{1}{\beta} \Phi^{\perp}\left(R_{\mu \nu}\right) \theta^{\perp}(l \Delta t)=\sum_{n=0}^{N-l} a_{n+l}^{\perp_{1}, \perp_{2}}\left(R_{\mu \nu}\right) a_{n}^{\perp_{1}, \perp_{2}}\left(R_{\mu \nu}\right)
\end{aligned}
$$

が成り立つ（Yoshimoto et al., 2013）。実際のタップ係数は, 記憶核の時間依存成分 $\theta^{\|, \perp}(t)$ に対するタップ係数をフ イッティングにより求めておき（図 9)，それらに粗視化粒子間距離に応じて $\sqrt{\Phi \|, \perp\left(R_{\mu \nu}\right) / \beta}$ を乗じることで計算 できる.なお，フィッティングには，非線形多変数関数のパラメータ探索に適した Nelder-Mead 法を用いた.

本研究では, 時間履歴の影響の有無を検討するための比較対象として, 時間履歴を考慮しないマルコフ DPD モ デルについても構築した. このモデルでは, $K_{\mu \nu}^{\|, \perp}\left(R_{\mu \nu}, t\right)=2 \gamma^{\|, \perp}\left(R_{\mu \nu}\right) \delta(t)$ と近似し, 散逸力を摩擦係数と粒子 間相対速度の積で，摇動力を時間相関のないランダム力で与える（Lei et al., 2010）．ランダム力の振幅は，第二 種摇動散逸定理を満たすように， $\sigma^{\|, \perp}=\sqrt{2 \gamma^{\|, \perp} k_{\mathrm{B}} T}$ で与えられる. なお，この DPD モデルのポテンシャルは NMDPD と同一であり, $3 \cdot 3$ 節の手順で取得したものを用いている. 


\section{NMDPD 水分子モデルの評価}

\section{$4 \cdot 1$ 平衡状態における NMDPD シミュレーション}

NMDPD の計算系は, 3・1 節で述べた MD 系に対応している. 即ち, 計算領域は, 全方向に周期境界条件が課

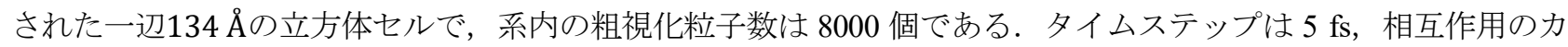
ットオフ距離は $20 \AA$ ，履歴効果の持続時間は $250 \mathrm{fs}$ である. 系の温度は，第二種摇動散逸定理に基づく熱浴によ り自動的に規定される. なお，式(13) で表現される記憶核は, 実装の段階で $K_{\mu \nu}^{\|, \perp}\left(R_{\mu \nu}, t\right)=A^{\|, \perp} \Phi^{\|, \perp}\left(R_{\mu \nu}\right) \theta^{\|, \perp}(t)$ と修正される. $A^{\|, \perp}$ は, VACF の再現性を高めるための修正係数である. 本研究では, この修正係数を変化させて $\mathrm{VACF}$ を比較し, 最終的に $A^{\|}=1.7, A^{\perp}=0.8$ という值を採用した. また, 前述のような MD 由来の相互作用を 取り込みつつ, 履歴を考慮しない DPD モデルについても同条件下で計算し, 履歴の影響の有無を検討している. まず，平衡状態における MD, DPD, NMDPD 系の温度を表 5 に示す. DPD 系の温度は MD 系の温度と一致してお り，DPD熱浴が正しく機能していることが示唆される，一方で，NMDPD 系の温度は MD 系の温度よりも若干高 くなっているが，差異は $3 \%$ 未満である，なお，タイムステップを小さくすると，NMDPD 系の温度は MD 系の ものに漸近していく. 計算精度と計算負荷のトレードオフを考慮した場合, 一般に, 粗視化系の温度の誤差が $3 \%$ 未満であれば，系の静的・動的特性はほとんど変化しないと考えられる（Groot and Warren, 1997）。従って，以降 のシミュレーションは，すべてタイムステップを $5 \mathrm{fs}$ として行った. なお， より粗視化レベルを上げる，即ちク ラスタの構成粒子数を増加させることで, クラスタ重心の運動の特性時間が長くなり, より大きなタイムステッ プを使用できる. その場合, 粗視化レベルは, 解析対象の解像度と計算負荷のトレードオフから決定される.

また，表 5 に平衡状態における MD, DPD, NMDPD 系の圧力も併せて示寸。これらは, MD, DPD, NMDPD の 各々について，50000 枚，20000 枚，20000 枚のスナップショットを 1 ブロックとしたものを 9 個用意し，各ブ

(a)

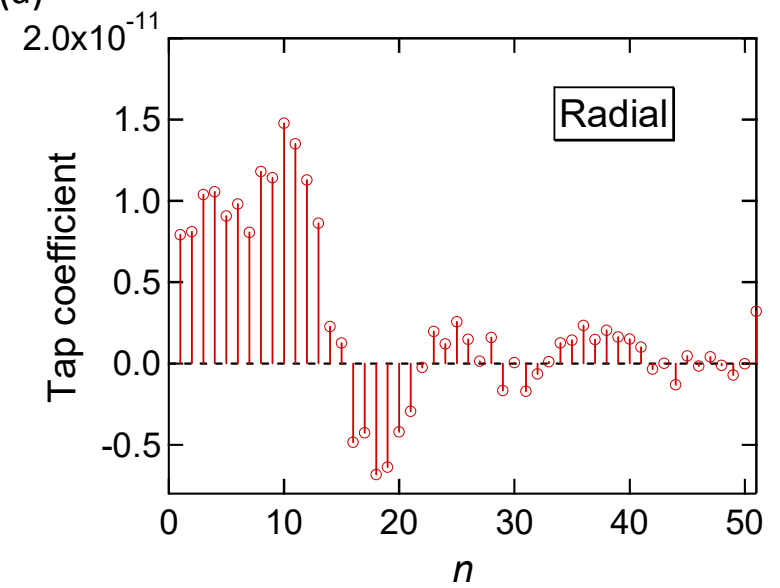

(c)

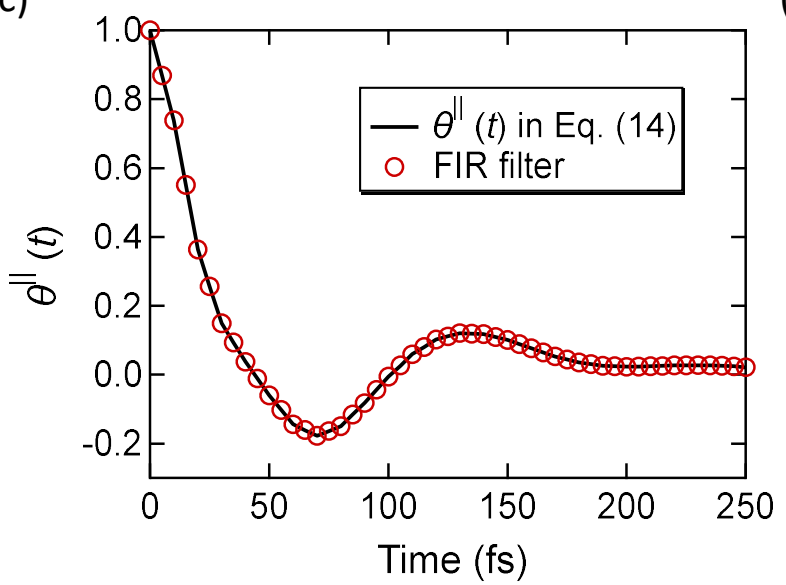

(b)

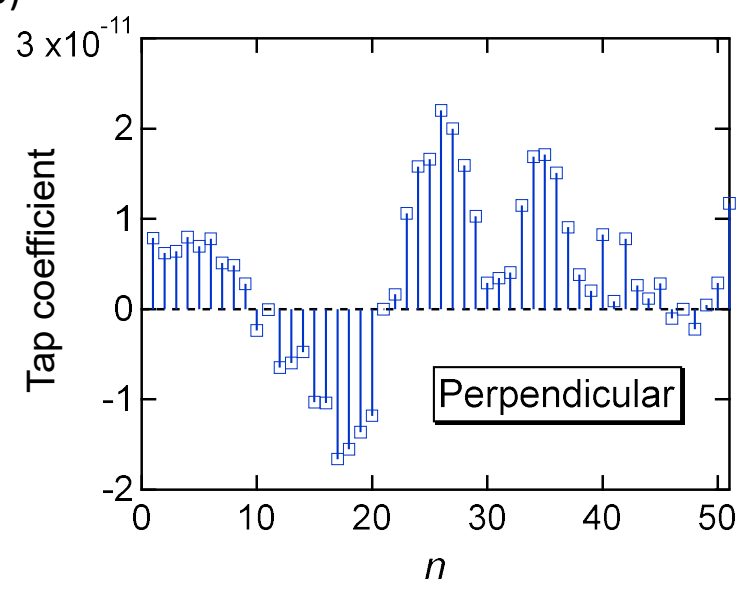

(d)

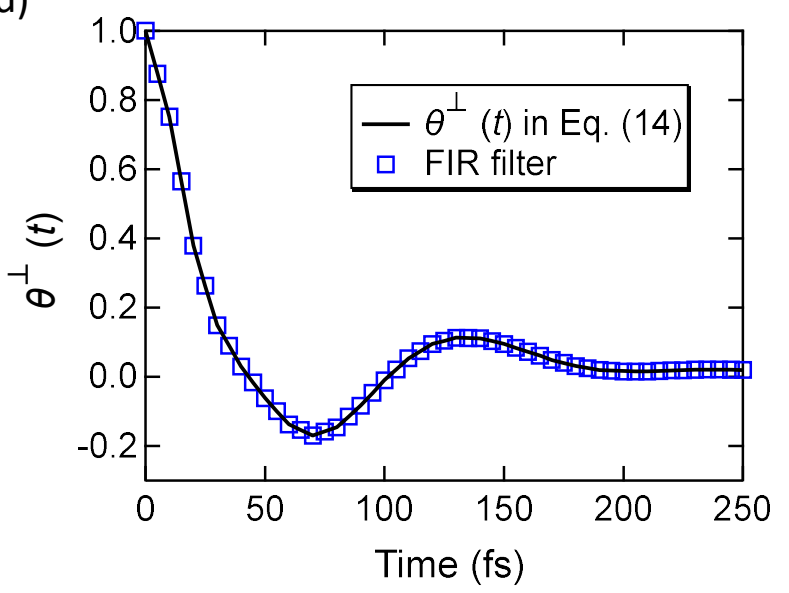

Fig. 9 Tap coefficients of the FIR filters for (a) $\theta^{\|}(t)$ and (b) $\theta^{\perp}(t)$. Equation (18) accurately represents (c) $\theta^{\|}(t)$ and (d) $\theta^{\perp}(t)$. 
ロックで圧力を求めた後，それらのブロック平均と標準誤差を計算したものである．圧力はポテンシャルモデル に著しく依存し, 数 MPa から数十 MPa のオーダーで変動する物理量であることを鑑みると, DPD と NMDPD はMD 系の圧力をよく再現しているといえる.さらに，NMDPD とDPD の RDF に関しては，図 4(b) に示した CGMD 系の RDF（破線）と同一であり，MD系のクラスタ重心の RDF（実線）と非常によい一致を示した。一般 に，圧力や RDF 等の静的特性は，ポテンシャルの精度に著しく依存する. 以上の結果から, MD から直接抽出さ れたポテンシャルに IBI 修正を施すことで（図 4(a)), 圧力と RDF を精度よく再現するポテンシャルを構築でき るといえる.

続いて, 系の動的特性を特徴づける VACF に着目する. VACF の短時間挙動は, 分子間衝突に起因する局所時 間・局所空間のダイナミクスにより規定される，一方で，VACF の長時間挙動は，拡散と粘性の形で発現する流 体力学的効果により規定される（Hansen and McDonald, 2013）。なお， 3 ・4節で述べた時間相関関数と同様，MD 系でクラスタ重心の VACF を計算する際は，不連続な変化を避けるために，クラスタの定義は更新しない．従っ て, VACF の計算時に MD クラスタの慣性半径は時々刻々と拡がっており (図 3(b)), MD 系と粗視化系の間の長 時間挙動の比較は必ずしも妥当ではないことに注意されたい，以上を踏まえ，図 10(a) に MD, DPD, NMDPD 系 の VACF の短時間挙動を示す. MD では $t=0$ 付近の VACF の傾きがおよそ 0 であるのに対して, DPD では VACF が急峻な傾きを示しており，MD で見られた弾道的挙動をうまく再現できていない。これは，DPDでは粗視化粒 子に時々刻々ランダム力が作用することに起因する. また，DPD では MD の VACF の湾曲を捉えられていない. 一方で, NMDPD では, $t=0$ 付近の弾道的な挙動や, VACF の湾曲をうまく再現できている. 以上から，履歴効 果を粗視化モデルに組み込むことで, 分子間衝突に起因する短時間ダイナミクスの精度が向上することが分かる.

次に，図 10(b) にVACF の長時間挙動を示す，DPD 系のVACF は単調減少しており，MD系の VACFに見られ るアンダーシュートを捉えられていない，一方で，NMDPD系の VACF はアンダーシュートを示しているが，MD に比べると深さが浅く, 速やかに 0 に漸近している.このように, DPDに比べると改善されてはいるが, 依然と

Table 5 Temperatures and pressures of the MD, DPD, and NMDPD systems.

\begin{tabular}{cccc}
\hline \hline & MD & DPD & NMDPD \\
\hline Temperature $(\mathrm{K})$ & 298 & 298 & 306 \\
\hline Pressure $\left(10^{5} \mathrm{~Pa}\right)$ & $9.3 \pm 0.3$ & $4.40 \pm 0.04$ & $6.65 \pm 0.03$ \\
\hline
\end{tabular}

(a)

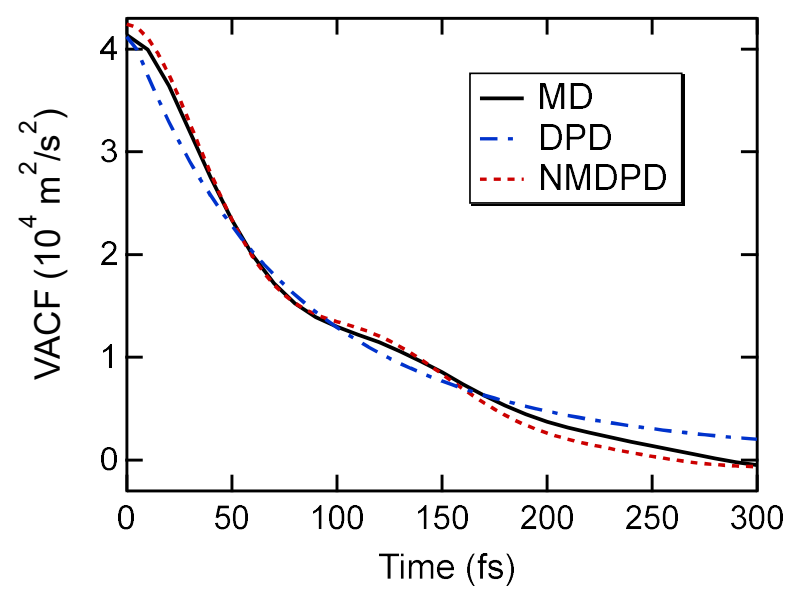

(b)

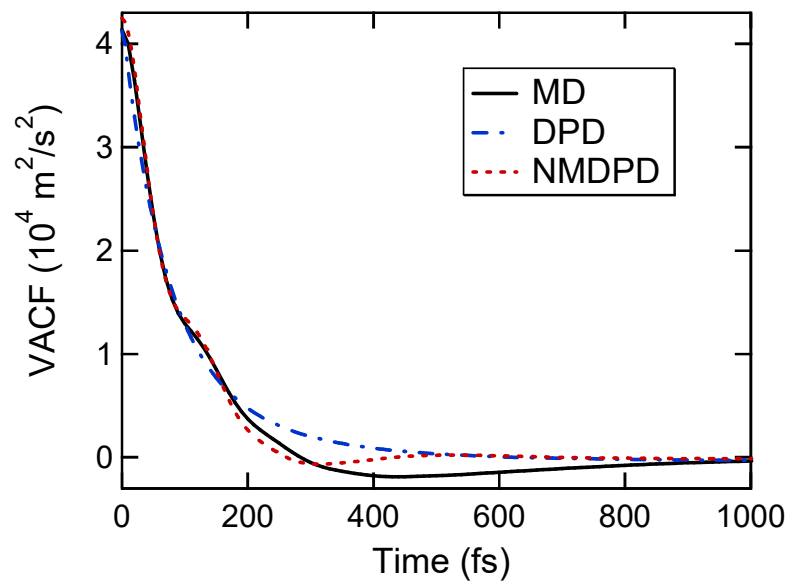

Fig. 10 Comparison of the velocity autocorrelation functions (VACFs) up to (a) $300 \mathrm{fs}$ and (b) $1000 \mathrm{fs}$. The short-time dynamics characterized by a decaying behavior of the MD VACF is better reproduced by the NMDPD model (left figure). Meanwhile, the undershoot of the MD VACF is not well represented even by the NMDPD model, although it also exhibits a slight undershoot of the VACF unlike the DPD model (right figure). 
して NMDPD と MD ではVACF の長時間挙動に差異が見られる. 先に述べたように, MD クラスタは時々刻々 と拡がっているため, 厳密に言えば, $t=0$ 以外では粗視化粒子と MD クラスタは一対一に対応していない. 従っ て, VACF の長時間挙動の差異は,「内部自由度のない」粗視化粒子という描像と,「構成粒子の拡がりが起こる」 MD クラスタの描像の差異に起因していると考えられる. しかしながら，MD クラスタの拡がりが比較的小さい 時間領域では，NMDPD とMD はよい一致を示していることから（図 10(a)），記憶核のモデリング自体は適切に なされているものと期待できる.

\section{$4 \cdot 2$ 非平衡状態における NMDPD シミュレーション}

非平衡状態における動的物性として，系内に対向する 2 つの Poiseuille 流れを誘起し，粘性係数を計算した （Backer et al., 2005)。計算領域は，全方向に周期境界条件が課された体積134 ×67 ×67 $\AA^{3}$ の直方体セルで，系 内の粗視化粒子数は 2000 個である. 系を $x$ 方向に 2 つの領域に分割し, 各領域の $y$ 方向に対向する外場をかけ る. それにより Poiseuille 流が誘起され，その平均流速から粘性を算出できる. 外場として与える加速度は $1.83 \times$ $10^{12} \mathrm{~m} / \mathrm{s}^{2}$ とし，MD系については Nosé-Hoover 熱浴（Nosé, 1984; Hoover, 1985）によって系全体の温度を $298 \mathrm{~K} に$ 保持した.

図 11 に MD, DPD, NMDPD 系の速度分布を示寸. DPD, NMDPD 系で速度分布はほぼ同一であり, MD 系より も平均流速が小さくなっている. 表 6 に示寸ように，粘性係数は MD に比べて，DPD, NMDPD ともに 1.8 倍程度 大きくなる．しかしながら，等温圧縮率や拡散係数等を再現するようにパラメータを規定する従来の現象論的な DPD（Groot and Warren, 1997; Groot and Rabone, 2001）では，粘性係数（もしくは Schmidt 数）が 2-3 桁程度の才 ーダーで過小評価されてしまうことに注意されたい，本研究で提案したように，MD シミュレーションから粗視 化ポテンシャルと記憶核を抽出することで，粘性係数の再現性が大幅に向上することが分かる.

一方で，DPD と NMDPD で粘性係数に差異はほぼ見られなかった。これは，粘性係数等の巨視的物理量は，記 憶核の関数形自体ではなく，その積分值に大きく依存するからと考えられる．即ち，NMDPD では記憶核を離散

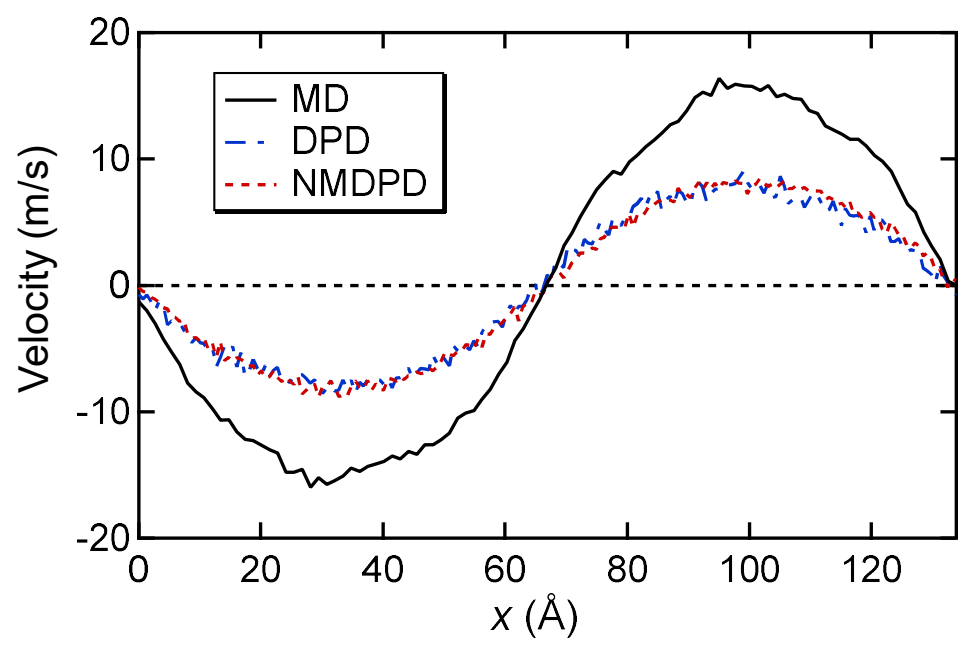

Fig. 11 Velocity profiles of Poiseuille flows in the MD, DPD, and NMDPD systems. Both the CG systems exhibit almost identical velocity profiles, indicating almost the same viscosities of the DPD and NMDPD models, which are about 1.8 times as large as the MD value as shown in Table 6.

Table 6 Viscosities of the MD, DPD, and NMDPD systems.

\begin{tabular}{lccc}
\hline \hline & MD & DPD & NMDPD \\
\hline Viscosity $\left(10^{-4} \mathrm{~Pa} \cdot \mathrm{s}\right)$ & 7.08 & 12.9 & 12.7 \\
\hline
\end{tabular}


化して陽に評価しているのに対し，DPD では記憶核の積分值を摩擦係数としているため, 流体力学的効果が発現 する時間スケールでは, 散逸力の実効的な影響が同程度になると考えられる. 一方で, 図 10(a) に示したように, 局所時間・局所空間でのダイナミクスにも着目寸る場合，記憶核の影響が顕著に現れる.

最後に, 粗視化系と MD系で粘性係数に差異が見られるのは, 粗視化粒子とMD クラスタの描像が必ずしも一 対一に対応していないことに起因すると考えられる. 即ち,「粗視化」の描像では, 粗視化粒子は同一の構成粒子 から成り, 内部自由度を持たず，外場中でも等方的な球形状となっている，一方で MD では，粗視化の都合上ク ラスタが定義されてはいるが，クラスタを構成寸る個々の分子はクラスタの定義とは無関係に外場の影響を受け ながら運動する．本研究で対象とした水に限らず，比較的低分子量の分子から成る溶媒をより正確に粗視化する ためには，上記の描像の差異を適切に埋める必要があると考えられる.

\section{5. 結 言}

本研究では, Mori-Zwanzig 射影演算子法と Iterative Boltzmann inversion(IBI) 法を用いて, 履歴効果を考慮した 非マルコフ散逸粒子動力学（Non-Markovian dissipative particle dynamics, NMDPD）に基づく水の粗視化モデルを構 築した. 分子動力学 (Molecular dynamics, MD) シミュレーションからクラスタ間の粗視化二体ポテンシャルを抽 出し，さらに IBI 法によって修正をかけることで，動径分布関数や圧力等の静的特性を再現するポテンシャルを 構築できることを示した. また, 一般化 Langevin 方程式に基づいて記憶核を抽出し, NMDPD に実装することで, マルコフ近似に基づく DPD に比べ, 速度自己相関関数で特徴づけられる動的特性, 特に分子間衝突に起因寸る 短時間ダイナミクスの精度が向上した．また，記憶核を MD からボトムアップ的に抽出することで，パラメータ チューニングに基づく従来の現象論的な DPD に比べて, 水の粘性係数をより妥当に再現することができた.

今後, 粗視化粒子と MD クラスタの描像をより適切に対応させることで, 粘性係数や速度自己相関関数の長時 間挙動をより正確に捉えられる粗視化モデルの構築を進めていく．また，本研究では，多成分系への拡張の前段 階として, 水の単成分系を扱った. 多成分系では, 異なる時間スケールを有する記憶核が複数存在し, 運動の特 性時間も粒子種毎に異なるため, 履歴効果を考慮した粗視化モデリングの有効性がより顕著になると考えられる. 加えて, 粗視化モデルの transferability を高めるためには, 温度や圧力をパラメータとして, 様々な熱力学的状態 点で同様の粗視化モデリングを行い，二体ポテンシャルや記憶核の温度・圧力に対する依存性を明らかにする必 要がある.これにより，二体ポテンシャルや記憶核を圧力や温度の関数として定義できれば，粗視化モデルの transferabilityを確保できると考えられる.

\section{References}

Allen, M. P. and Tildesley, D. J., Computer simulation of liquids, Clarendon Press, New York (1989).

Backer, J. A., Lowe, C. P., Hoefsloot, H. C. J. and Ledema, P. D., Poiseuille flow to measure the viscosity of particle model fluids, The Journal of Chemical Physics, Vol. 122, No. 15 (2005), 154503.

Berendsen, H., Grigera, J. R. and Straatsma, T. P., The missing term in effective pair potentials, The Journal of Physical Chemistry, Vol. 91, No. 24 (1987), pp. 6269-6271.

Dror, R. O., Dirks, R. M., Grossman, J. P., Xu, H. and Shaw, D. E., Biomolecular simulation: A computational microscope for molecular biology, Annual Review of Biophysics, Vol. 41, No. 1 (2012), pp. 429-452.

Español, P. and Warren, P., Statistical mechanics of dissipative particle dynamics, Europhysics Letters, Vol. 30, No. 4 (1995), pp. 191-196.

Fan, X., Phan-Thien, N., Chen, S., Wu, X. and Ng, T. Y., Simulating flow of DNA suspension using dissipative particle dynamics, Physics of Fluids, Vol. 18, No. 6 (2006), 063102.

Fennell, C. J. and Gezelter, J. D., Is the Ewald summation still necessary? Pairwise alternatives to the accepted standard for long-range electrostatics, The Journal of Chemical Physics, Vol. 124, No. 23 (2006), 234104.

Groot, R. D., Madden, T. J. and Tildesley, D. J., On the role of hydrodynamic interactions in block copolymer microphase separation, The Journal of Chemical Physics, Vol. 110, No. 19 (1999), pp. 9739-9749. 
Groot, R. D. and Rabone, K. L., Mesoscopic simulation of cell membrane damage, morphology change and rupture by nonionic surfactants, Biophysical Journal, Vol. 81, No. 2 (2001), pp. 725-736.

Groot, R. D. and Warren, P. B., Dissipative particle dynamics: Bridging the gap between atomistic and mesoscopic simulation, The Journal of Chemical Physics, Vol. 107, No. 11 (1997), pp. 4423-4435.

Hansen, J. P. and McDonald, I. R., Theory of simple liquids, 4th ed. Academic Press (2013).

Hockney, R. W. and Eastwood, J. W., Computer simulation using particles, Routledge (1988).

Hoogerbrugge, P. J. and Koelman, J. M. V. A., Simulating microscopic hydrodynamic phenomena with dissipative particle dynamics, Europhysics Letters, Vol. 19, No. 3 (1992), pp. 155-160.

Hoover, W. G., Canonical dynamics: Equilibrium phase-space distributions, Physical Review A, Vol. 31, No. 3 (1985), pp. 1695-1697.

Hummer, G., Rasaiah, J. and Noworyta, J., Water conduction through the hydrophobic channel of a carbon nanotube, Nature, Vol. 414, No. 6860 (2001), pp. 188-190.

Ingolfsson, H. I., Lopez, C. A., Uusitalo, J. J., Jong, D. H., Gopal, S. M., Periole, X. and Marrink, S. J., The power of coarse graining in biomolecular simulations, WIREs Computational Molecular Science, Vol. 4, No. 3 (2014), pp. $225-248$.

Junghans, C., Praprotnik, M. and Kremer, K., Transport properties controlled by a thermostat: An extended dissipative particle dynamics thermostat, Soft Matter, Vol 4, No. 1 (2008), pp. 156-161.

Kinjo, T. and Hyodo, S., Equation of motion for coarse-grained simulation based on microscopic description, Physical Review E, Vol.75, No. 5 (2007), 051109.

Komarov, P. V., Khalatur, P. G. and Khokhlov, A. R., Large-scale atomistic and quantum-mechanical simulations of a Nafion membrane: Morphology, proton solvation and charge transport, Beilstein Journal of Nanotechnology, Vol. 4, No. 1 (2013), pp. 567-587.

Lei, H., Caswell, B. and Karniadakis, G. E., Direct construction of mesoscopic models from microscopic simulations, Physical Review E, Vol. 81, No. 2 (2010), 026704.

Li, Z., Xin, B., Li, X. and Karniadakis, G. E., Incorporation of memory effects in coarse-grained modeling via the MoriZwanzig formalism, The Journal of Chemical Physics, Vol. 143, No. 24 (2015), 243128.

Marín, Á. G., Gelderblom, H., Lohse, D. and Snoeijer, J. H., Order-to-disorder transition in ring-shaped colloidal stains, Physical Review Letters, Vol.107, No. 8 (2011), 085502.

Mori, H., Transport, collective motion, and Brownian motion, Progress of Theoretical Physics, Vol. 33, No. 3 (1965), pp. 423-454.

Nelder, A. and Mead, R., A simplex method for function minimization, The Computer Journal, Vol. 7, No. 4 (1965), pp. 308-313.

Nosé, S., A unified formulation of the constant temperature molecular-dynamics methods, The Journal of Chemical Physics, Vol. 81, No.1 (1984), pp. 511-519.

Oppenheim, A. V., Schafer, R. W. and Buck, J. R., Discrete-time signal processing, 2nd ed., Prentice Hall (1999).

Plimpton, S., Fast parallel algorithms for short-range molecular dynamics, Journal of computational physics, Vol. 117, No. 1 (1995), pp. 1-19.

Reith, D., Pütz, M. and Müller-plathe, F., Deriving effective mesoscale potentials from atomistic simulations, Journal of Computational Chemistry, Vol. 24, No. 13 (2003), pp. 1624-1636.

Rühle, V., Junghans, C., Lukyanov, A., Kremer, K. and Andrienko, D., Versatile object-oriented toolkit for coarse-graining applications, Journal of Chemical Theory and Computation, Vol. 5, No. 12 (2009), pp. 3211-3223.

Sun, M., Li, B., Li, Y., Liu, Y., Liu, Q., Jiang, H., He, Z., Zhao, Y. and Sun, J., Experimental observations and dissipative particle dynamic simulations on microstructures of $\mathrm{pH}$-sensitive polymer containing amorphous solid dispersions, International Journal of Pharmaceutics, Vol. 517, No. 1-2 (2016), pp. 185-195.

Yoshimoto, Y., Kinefuchi, I., Mima, T., Fukushima, M., Tokumasu, T. and Takagi, S., Bottom-up construction of interaction models of non-Markovian dissipative particle dynamics, Physical Review E, Vol. 88, No. 4 (2013), 043305. 
Kihara, Yoshimoto, Hori, Takagi and Kinefuchi, Transactions of the JSME (in Japanese), Vol.84, No.865 (2018)

Yoshimoto, Y., Li, Z., Kinefuchi, I. and Karniadakis, G. E., Construction of non-Markovian coarse-grained models employing the Mori-Zwanzig formalism and iterative Boltzmann inversion, The Journal of Chemical Physics, Vol. 148, No. 24 (2017), 244110.

Zwanzig, R., Ensemble method in the theory of irreversibility, The Journal of Chemical Physics, Vol. 33, No. 5 (1960), pp. $1338-1341$. 